\title{
ETHNOMEDICINAL STUDY OF SOME PLANTS USED AS SPICES BY THE INHABITANTS OF KANO METROPOLIS, NORTHERN NIGERIA
}

\author{
${ }^{*}$ Negbenebor, H.E., ${ }^{1}$ Mairami, F.M., ${ }^{1}$ and Nura, S. ${ }^{2}$ \\ 1. Department of Computing and Applied Science, Baze University, Abuja, Nigeria. \\ 2. Department of Biology, Ahmadu Bello University Zaria, Nigeria. \\ *Corresponding author: helen.ehimemen@bazeuniversity.edu.ng GSM: +2348023103439
}

\begin{abstract}
$A$ research was conducted to study the ethnomedicinal importance of some plants used as spices by the indigenous people of Kano metropolis. The research was conducted within four selected markets in the area. A self-designed questionnaire was used as a tool for data collection. The result obtained revealed the presence of fourteen different plant species representing nine families used as spices. These spices were found to be very effective against several clinical symptoms such as rheumatism, pneumonia, stomachache, fever, pile and ulcerative colitis among others. They also served as hypolipidemic, antithrombotic, antihypertensive, anti-hyperglycemic, antihypercholesterolemic and immuno-modulatory as well as anticancer agents. Garlic, clove, ginger, nutmeg and chilli pepper are the most predominant spices used in the area with relative frequent use of $25 \%, 24 \%, 21 \%, 15 \%$ and $9 \%$ respectively. The research also discovered their methods of preparation to vary from one location to another within the area. However, despite the roles they play in adding taste and flavor and nutritional composition to the diets, their usage is declining probably due to changing pattern of food choice and urbanization coupled with economic melt-down. There is therefore the need to call the attention of the health care sector to review the medicinal value of the spices and involve their applications into therapeutic diets.
\end{abstract}

Key words: Clove, Ethnomedicine, Garlic, Ginger, Onion,

\section{INTRODUCTION}

Spices are any part of a plant such as dried seed, fruit, root, bark,

or vegetable substance primarily used for flavoring, seasoning,

coloring or preserving food. These spices played an integral role in enhancing the taste of foods, beverages and drugs (Schippers, 2000) as well as having antimicrobial (Anonymous, 2013a) and anticancer properties. This may explain why spices are more commonly used in warmer climates, which have more infectious disease, and why the use of spices is prominent in meat, which is particularly prone to spoilage. Spices are the most widely utilized plant species in Nigeria (Kayode and Ogunleye, 2008).

The knowledge and use of plants as spices is as old as the history of mankind (Garland, 1972). The use of spices in Hausa culture is an established fact as it was made an integral part in the baptism of newborn and food preparations of pregnant and newly delivered nursing mothers to boost their immune responses. However, despite the nutraceutical, pharmaceutical and commercial importance of spices to Hausa people, available information about ethnomedicinal value of the spices is lacking. Available studies carried out in the area fail to explore the ethnomedicinal applications of these important plants.
Kano state of Nigeria is located between latitude $10^{\circ} 30^{\prime} \mathrm{N}$ and $13^{\circ} 03^{\prime} \mathrm{N}$. It has Sudan savannah type of climate and vegetation that gradually gives way to semi-arid conditions northward. It is a part of the Hausa land where ethnomedicine is recognized and practiced (Hussain and Deeni, 1991). The area is rich in plants with high medicinal value. The area has a long history of civilization as such the use of medicinal plants is a heritage. This research therefore aimed at investigating the different types of plants used as spices in Kano metropolis with the view of providing data on the ethnobotanical and ethnomedicinal applications of plants used as spices. Attempt is made to also provide the most acceptable scientific, common and local, names for the various species.

\section{MATERIALS AND METHODS}

Study Area

The research was conducted in the state capital of Kano State in Northwestern part of Nigeria. It is situated in the Sahelian savanna zone that lies $12^{\circ} \mathrm{N}$, south of the Sahara on an altitude of $481 \mathrm{~m}$ above sea level. Kano state is the commercial nerve center of Northern Nigeria and is the most highly populated area in Nigeria with over 15 million people. 
The Kano metropolis comprised eight local government areas that include: Kano Municipal, Fagge, Dala, Gwale, Tarauni and Nasarawa, Ungogo and Kumbotso local government areas. The total area of Metropolitan Kano is now 499 $\mathrm{km}^{2}$, with a population of $2,828,861$ as of the 2006 Nigerian census. Majority of the inhabitants are Hausa and Fulani ethnic groups (Anonymous, 2013b). The vegetation of the area is a typical savanna type with dominant grasses and scattered trees that are mostly with fire resistant barks and semi-arid climate.

\section{Experimental Design}

The research was conducted in four markets of Kano metropolis. The markets comprised of 'BakinAsibiti' market, 'KofarWambai' market, 'Kurmi' market and 'SabonGari' market. A selfstructured questionnaire was used to gather the data used in this research. A total of 480 subjects were sampled using simple random sampling technique. Due to the low Western education level or lack of understanding of the English language of some of the subjects, the structured questionnaires were discussed on an individual basis and explained by the researchers using their interviewees native language (Hausa language) which is also the first language of most of the researchers. The results were then transcribed by the researchers as many could not write. A total of 480 individuals were interviewed, comprising of spices sellers and buyers. Many of the spices sellers and buyers provided the local names of the plants used. Identification and scientific names of the plants were validated in the herbarium of the department of Biological Sciences, Ahmadu Bello University, Zaria, Nigeria; where possible, voucher specimens were obtained. The data obtained was analyzed using frequency and percentages.

\section{RESULTS AND DISCUSSION}

The result obtained revealed that most of the people that used spices are elderly people who are 50 years to above (Table 1) and are mostly females (Table 2 ). This can probably be due to the fact that the use of spices is associated more or less with the cultural norms and values of Hausa people and females especially the elderly are the custodians.

Table 1: Age Range of Respondents

\begin{tabular}{cccc}
\hline S/N & Age Range & Frequency & Percentage (\%) \\
\hline 1 & $20-29$ Years & 5 & 1.04 \\
2 & $30-39$ years & 68 & 14.17 \\
3 & $40-49$ years & 138 & 28.75 \\
4 & 50 years-above & 269 & 56.04 \\
\hline TOTAL & & 480 & $100 \%$ \\
\hline
\end{tabular}

Table 2: Distribution of theRespondents based on Gender

\begin{tabular}{cccccc}
\hline S/N & HERBAL & Frequency of & Percentage of & Frequency of & Percentage of \\
& MARKETS & Males & Males & 118 & 98.33 \\
\hline 1 & BakinAsibiti & 2 & 1.67 & 114 & 95 \\
2 & KofarWambai & 6 & 5 & 83 & 69.17 \\
3 & Kurmi Market & 37 & 30.83 & 96 & 80 \\
4 & SabonGari & 24 & 20 & 411 & 85.62 \\
\hline
\end{tabular}

The most commonly used spices (Table 3 ) are garlic, clove, ginger, nutmeg and chilli pepper with relative frequent use of $25 \%, 24 \%, 21 \%, 15 \%$ and $9 \%$ respectively.

Table 3: Relative Distribution of Spices used by the Respondents

\begin{tabular}{|c|c|c|c|}
\hline $\mathrm{S} / \mathrm{N}$ & Responses & Frequency & Percentage (\%) \\
\hline 1. & Allium cepa & 5 & 1 \\
\hline 2. & Allium sativum & 120 & 25 \\
\hline 3. & Solanum incanum & 3 & 1 \\
\hline 4. & Syzygium aromaticum & 115 & 24 \\
\hline 5 & Tamarindus indica & 5 & 1 \\
\hline 6 & Zingiber officinale & 101 & 21 \\
\hline 7 & Myristica fragans & 72 & 15 \\
\hline 8 & Piper nigrum & 4 & 1 \\
\hline 9 & Capsicum frutescens & 43 & 9 \\
\hline 10 & Capsicum annuum & 2 & 0.5 \\
\hline 11 & Curcuma longa & 1 & 0.3 \\
\hline 12 & Xylopia aethiopica & 4 & 1 \\
\hline 13 & $\begin{array}{l}\text { Lycopersicon } \\
\text { lycopersicum }\end{array}$ & 1 & 0.2 \\
\hline 14 & Ocimum gratissimum & 4 & 1 \\
\hline TOTAL & & 480 & $100 \%$ \\
\hline
\end{tabular}


More so, $95 \%$ of the respondents are of the view that spices played a great vital role in traditional medi-cure (Table 4) and hence if properly managed can serve as alternatives to conventional medicine. This is in conformity with the findings of Lewington (1990), Mann (2011) and Green et al. (2012) who independently reported the medicinal values of different spices in Nigeria.

Table 4: Purposes for the use of Spices by the Respondents

\begin{tabular}{cccc}
\hline S/N & Responses & Frequency & Percentage (\%) \\
\hline 1. & Medicinal Purpose & 456 & 95.00 \\
2. & Cultural Heritage & 17 & 3.54 \\
3. & Preservation & 7 & 1.46 \\
4. & Others & 0 & 0.00 \\
\hline TOTAL & & 480 & $100 \%$ \\
\hline
\end{tabular}

However, despite the wide range of culinary and medicinal importance of spices, its usage is declining among the Hausa people due to changing nature of food choice and modern life styles of many youths (Table 5). The use of some spices is seen as a sign of poverty among people.

Table 5: Reasons for the Decline in Using Spices

\begin{tabular}{cccc}
\hline $\mathrm{S} / \mathrm{N}$ & Responses & Frequency & Percentage (\%) \\
\hline 1. & $\begin{array}{c}\text { High cost of } \\
\text { conventional } \\
\text { medicine } \\
\text { Change in Food }\end{array}$ & 29 & 6.04 \\
2. & Choice & 353 & 73.54 \\
3. & Urbanization & 98 & 20.42 \\
4. & Others & 0 & 0.00 \\
\hline TOTAL & & 480 & $100 \%$ \\
\hline
\end{tabular}

The most commonly used spices in Kano are shown in Table 6 . The result showed that spices are effective against Rheumatism, hypolipidemy, thrombosis, hypertension, hyperglycemia, hypercholesterolemia and immuno-modulatory as reported by Krishnaraj (1997) and Block (1998), Also, onion is used as Anti-Anorexia, anti-arteriosclerosis, and against stomachache, ulcerative colitis, colds, cough, asthmas and diabetes by onions as reported by van Wyk and Wink, (2005). Other spices such as clove are used against toothache as reported by Phyllis and James (2000), ginger against pregnancy complications such as nausea and vomiting as reported by Southgate (1993). Nutmeg has been used against digestive tract disorders such as stomach cramps and diarrhea, as well as catarrh of the respiratory tract as reported by Tajuddin et al. (2003). Black pepper, chilli pepper, and red pepper were used against Gastro Intestinal Tract (GIT) disorders. This is also reported by JensenJarolim et al. (1998). Furthermore, tomatoes, turmeric and ginger were known for their anticancer properties as reported by Ohaeri and Adoga (2006) and Mann (2011). These spices have different methods of preparations.Thus, besides the culinary significance of Hausa spices they played a great therapeutic role in Hausa traditional pharmacopoeia. 
Special Conference Edition, November, 2017

Table 6: Plants Used as Spices in Kano

\begin{tabular}{|c|c|c|c|c|c|c|}
\hline $\mathrm{S} / \mathrm{N}$ & BOTANICALNAME & $\begin{array}{c}\text { Vernacular } \\
\text { Name } \\
\text { (Hausa) }\end{array}$ & $\begin{array}{l}\text { Common } \\
\text { Name }\end{array}$ & Family & Parts Used & $\begin{array}{l}\text { Medicinal } \\
\text { Uses }\end{array}$ \\
\hline 1 & Allium cepa & Albasa & Onion & Liliaceae & Bulb & GIT Disorders \\
\hline 2 & Allium sativum & Tafarnuwa & Garlic & Liliaceae & Bulb & $\begin{array}{c}\text { Rheumatism, } \\
\text { anti- } \\
\text { hypertensive, } \\
\text { anti- } \\
\text { hyperglycemic. }\end{array}$ \\
\hline 3 & 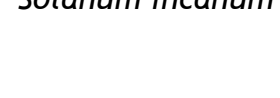 & Gauta & Garden egg & Solanaceae & Fruits & $\begin{array}{c}\text { Anti-darrhoea, } \\
\text { piles }\end{array}$ \\
\hline 4 & $\begin{array}{l}\text { Syzygium } \\
\text { aromaticum }\end{array}$ & Kanumfari & Clove & Myrtaceae & Seeds & $\begin{array}{l}\text { Toothache, } \\
\text { piles. }\end{array}$ \\
\hline 5 & $\begin{array}{l}\text { Tamarindus } \\
\text { indica }\end{array}$ & Tsamiya & Tamarind & Poaceae & Fruits & $\begin{array}{l}\text { GIT Disorders, } \\
\text { vomiting, } \\
\text { nausea }\end{array}$ \\
\hline 6 & $\begin{array}{l}\text { Zingiber } \\
\text { officinale }\end{array}$ & Citta & Ginger & Zingiberaceae & Rhizome & $\begin{array}{c}\text { Pregnancy } \\
\text { complications, } \\
\text { colds, GIT } \\
\text { Disorders }\end{array}$ \\
\hline 7 & Myristica fragans & Masoro & Nutmeg & Myristicaceae & Seeds & $\begin{array}{l}\text { GIT Disorders, } \\
\text { piles }\end{array}$ \\
\hline 8 & Piper nigrum & Tattasai & Black pepper & Piperaceae & Fruits & GIT Disorders \\
\hline 9 & $\begin{array}{l}\text { Capsicum } \\
\text { frutescens }\end{array}$ & Barkono & Chilli pepper & Solanaceae & Fruits & GIT Disorders \\
\hline 10 & $\begin{array}{l}\text { Capsicum } \\
\text { annuum }\end{array}$ & Attaruhu & Red pepper & Solanaceae & Fruits & GIT Disorders \\
\hline 11 & Curcuma longa & Zabibi & Turmeric & Zingiberaceae & Rhizome & Anti-cancer \\
\hline 12 & $\begin{array}{c}\text { Xylopia } \\
\text { aethiopica }\end{array}$ & Kimba & $\begin{array}{l}\text { Negro } \\
\text { pepper }\end{array}$ & Annonaceae & $\begin{array}{l}\text { Seeds and } \\
\text { fruits }\end{array}$ & Piles \\
\hline 13 & $\begin{array}{l}\text { Lycopersicon } \\
\text { lycopersicum }\end{array}$ & Tumatur & Tomato & Solanaceae & Fruits & $\begin{array}{l}\text { Anti-cancer, } \\
\text { skin rashes }\end{array}$ \\
\hline 14 & $\underset{\text { gratissimum }}{\text { Ocimum }}$ & Daddoya & Basil & Lamiaceae & $\begin{array}{l}\text { Leaves and } \\
\text { seeds }\end{array}$ & Cold \\
\hline
\end{tabular}

\section{CONCLUSION}

It was concluded that there are vast array of plants used as spices in Kano metropolis which

\section{REFERENCES}

Anonymous http://www.wikipedia.org. Retrieved April 6 ${ }^{\text {th }}, 2016$.

Anonymous (2013b): Kano State. http://www.wikipedia.org. Retrieved $22^{\text {nd }}$ September, 2016.

Block, E. (1998): The organosulfur and organoselenium components of garlic and onions. In:

Bidlack WR, Omaye ST, Meskin MS, Jahner D (eds.). Phytochemicals - a new are used for both culinary and medicinal purposes and also their methods of preparations differ.

paradigm. Technomic Publishing, Lancaster. pp. 129-141.

Garland, S. (1972): The Herbs and spices Book. Frances Lincoln Publishers, London pp. 20-27.

Green, B.O., Nworgu, F.C., and Obazee, M.N. (2012): Spices and food condiments in Niger- Delta region of Nigeria. African Journal of Biotechnology, 11(79): 14468-144573. 
Hussain, H.S.N., and Deeni, Y.Y. (1991): Plants in Kano ethnomedicine; Screening for antimicrobial activity and alkaloids. Pharmaceutical Biology, 29(1):51-56.

Jensen-Jarolim, E., Gajdzik, L., Haberl, I., Karaft, D., Scheiner, O., and Graf, J. (1998): Hot spices influence permeability of human intestinal epithelial monolayers. Journal ofNutrition, 128: 577-581.

Kayode, J., and Ogunleye, T.O. (2008): Checklist and Status of Plant Species Used as Spices in Kaduna State of Nigeria.African Journal of General Agriculture, 4(1): 13-18.

Krishnaraj, R. (1997): International phytotherapeutic uses of garlic food forms. In: Lachance PA (ed.). Nutraceuticals: designer foods III Garlic,soy and licorice. Food and Nutrition Press, Connecticut, pp. 71-80.

Lewington, A.A. (1990): Plant for people. Oxford University Press, New York pp 90-95.

Mann, A. (2011): Biopotency role of culinary spices and herbs and their chemical constituents in health and commonly used spices in Nigerian dishes and snacks. African Journal of Food Science, 5(3): 111-124.
Ohaeri, O.C., and Adoga, G.I. (2006): Anticoagulant modulation of blood cells and platelet reactivity by garlic oil in experimental diabetes mellitus. Biosci.Rep., 26: 1-6.

Phyllis, B., and James, B. (2000): Prescription for Nutritional Healing. $3^{\text {rd }}$ ed., Avery Publishing, $94 \mathrm{pp}$.

Schippers, R.R. (2000). African indigenous vegetables: An overview of cultivated species. Natural Resources Institute/ACP-EU Technical Centre for Agricultural and Rural Cooperation, Chatham, Uk, 214pp.

Southgate, D.A.T. (1993): Spices and Beverages. In: Essential Human Nutrition and Dietetics.

Tajuddin, A.S., Latif, A., and Qasmi, I.A. (2003): Aphrodisiac activity of 50\% ethanolic extracts of Myristica fragrans Houtt. (nutmeg) and Syzgium aromaticum (L) Merr. and Perry (Clove) in male mice: a comparative study. BMC Complement. Alternative Medicine, 3: 6.

Wyk, V., and Wink, M. (2005). Medicinal Plants of the World. Briza Pulications, Pretoria, South Africa.pp. 38- 349. 